\title{
Social Identity and Perceived Importance of the Profession
}

\author{
Jayanti Roy Ph.D. \\ Associate Professor of Psychology \\ Goodwin College, Connecticut, USA
}

\begin{abstract}
Social identity of professionals is enhanced at their association meetings. A strong social identity later promotes the advocacy for the importance of the profession. For e.g. nurses who have a strong professional identity would advocate for the importance of their profession (nursing) at their organizations viz. hospitals. Local chapters of professional associations provide education and networking opportunities with similar professionals. Yet, attendance at local chapter meetings tends to be a challenge. This paper examines the link of social identity, past participation, program content, delivery mode and co-production with the professional association and the perceived importance of the profession in the member's organization. I investigate the link of the importance of the profession to advocacy initiatives that the member might undertake in her or his organization. The paper offers a model and conducts a survey of association members and finds that social identity alone is not a significant predictor of the perceived importance of the profession but social identity operates interactively with other relevant variables like past participation, program content, delivery mode of association programs.

"1.1.1 Local chapters of AAPC are essential in setting the standard of professionalism and higher education, while developing personal improvement and strong networking opportunities." Page 12018 AAPC Local Chapter Handbook. (AAPC 2018) ${ }^{1}$
\end{abstract}

\subsection{Introduction}

Social identity involves how we define our own identity based on the groups we belong to and how our identity in turn both influences and influenced by the groups we belong to. A long stream of research on Social identity theory (e.g. Ethier\& Deaux, 1994; Tajfel, 1981) examines how our social identity is influenced by groups and how we in turn influence groups (Postmes et. al., 2005) based on our social identity. This research explores the influence of professional associations on an individual member's social identity and its effect on the member enhancing the importance of the profession back in her/his organization.

Social identity of professionals is enhanced at their association meetings. A strong social identity with the profession leads to the advocacy for the importance of the profession. For e.g. nurses who have a strong professional identity would advocate for the importance of their profession (nursing) at their organizations viz. hospitals (Hoeve et. al., 2014).

Professional associations serve the adult learning and professional development needs of professions (Rusaw, 1995). Professional association meetings can be held at local, state, national and international levels. Such meetings involve learning from one another in a social context and also learning from speakers invited to speak. Members keep themselves updated by understanding how a particular work challenge is resolved by another member in a different organization and context. Ideas to take back to improve outcomes in their work context becomes a direct benefit of such attendance. Professions like health services and accounting have certifications and credentialing (Weddie et. al., 2002) and frequently require members to attend and earn educational credits to ensure that professional members do at least the minimum amount of educational credits.

Prior research (Mair\& Thompson, 2009) has explored the decision process of attending a conference that involve costs of travel, stay and registration fees there. On the organizing side of meetings, the leadership of professional associations are charged with engaging their members to attend their events. Towards this the leadership follows Local Chapter guidelines as developed by the National Association. An example of such guidelines is in the handbook of the AAPC, formerly American Association of Professional Coders (AAPC, 2018).

\footnotetext{
${ }^{1}$ AAPC is the association of medical coders and the quote from their handbook illustrates the efforts that professions make in trying to build local community in their professions.
} 
There is sparse research on attendance challenges at local association chapter meetings. This is surprising for four reasons. First, attendance at most local chapter meetings is low - sometimes as low as less than $10 \%$ of the Chapter members. Second, if members do not attend meetings they cannot experience the benefits of the membership and wonder if they are getting value from the membership fees. Third, the paradox is that given that local chapter meetings normally involve only marginal costs ${ }^{2}$ beyond the annual membership fee, why members do not attend is a mystery. Finally, if members do not attend the meetings they do not develop a social identity that helps promote the importance of the profession at their organizations.

Professional associations and their affiliates are "understood as agents of reproduction rather than change" (Greenwood, Suddaby\& Hinnings, 2000, p.72). However, as Greenwood, Suddaby\& Hinnings (2002) conclude associations can play a significant role in institutionalizing change. Certain professions like purchasing, human resources and nursing operate primarily in context of organizations as a department or function. For such professions the role of the professional includes advocacy for their professional causes at their organization. Such causes include social marketing causes like "greening" the supply chain for the purchasing profession and promoting employee diversity for the human resource profession. This paper argues that in professions that are primarily organization based, like purchasing the engagement of members with the association activities can influence the changing status of the profession in the organization. In doing so, I integrate relationship perspectives on member-association links and social identity derived from the professional association. (eg. Gruen, Summers, \&Acito, 2000; Cannon \& Homburg, 2001; Wilson \& Woodside, 2001). I offer a conceptual model and test my theoretical model and offer insights to the learning and networking in professional associations. I contribute to the professional association-member engagement literature and the learning, culture and social interaction literature. The article is organized as follows; Section 2 introduces the conceptual model and hypotheses, Section 3 describes the context and method of the study, Section 4 explains the testing and results, Section 5 discusses the implications for social marketing research and practice and finally Section 6 offers the limitations and directions for future research.

\subsection{Conceptual model and hypotheses}

Professional associations attempt to enhance member engagement through offering relevant programs, providing networking opportunities and enhancing the image of the profession (Gruen, Summers, \&Acito, 2000). Like other professional associations the identification of members with the association enhances their engagement with the association the profession and its prestige. This in turn promotes the importance of the profession through the advocacy of the members.

I conceptualize the model as in Figure 1

Figure 1. Social Identity and Perceived Importance of the Profession

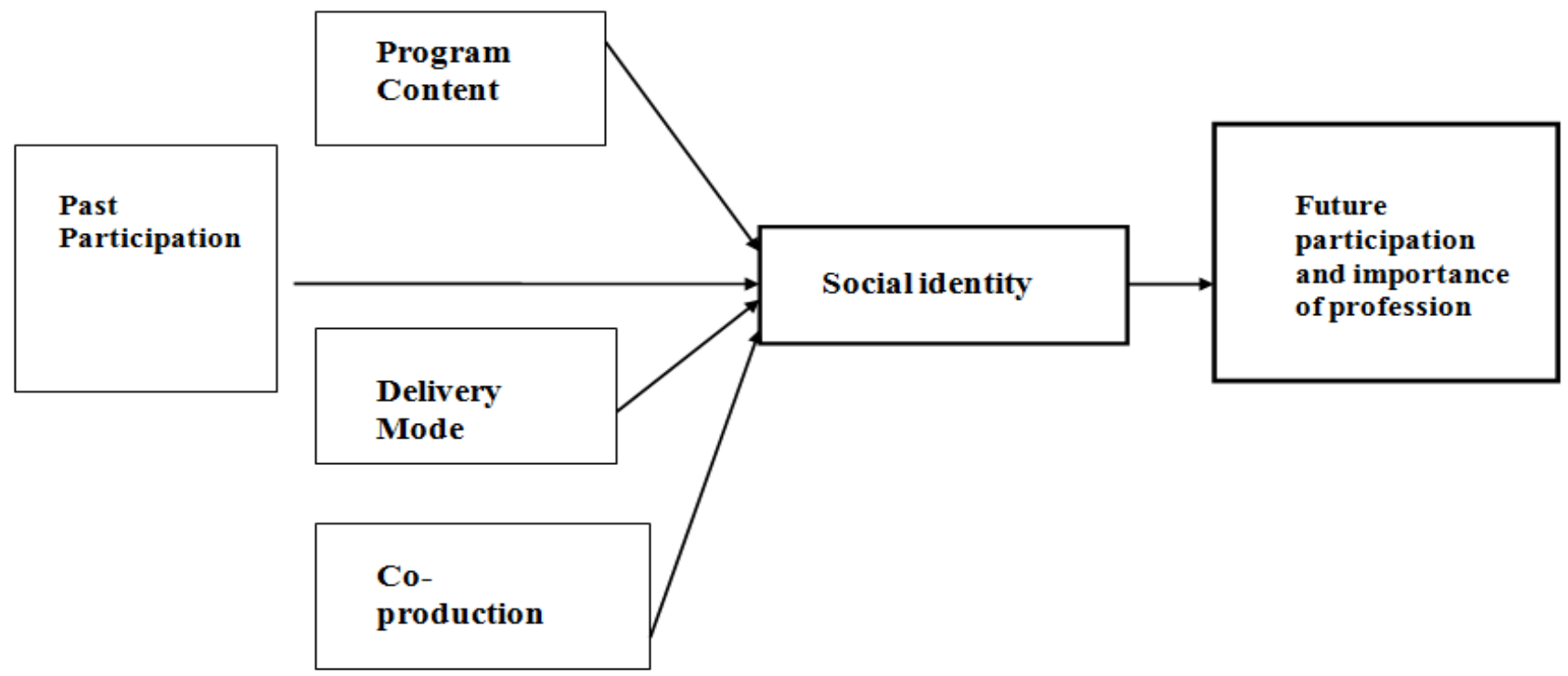

\footnotetext{
${ }^{2}$ Thus, if a Professional Association member wants to attend the annual national meeting/conference that involves air travel, hotel and registration costs can easily cross $\$ 2000$. However, local chapter meetings are frequently free or may cost under $\$ 20$ to cover incremental food/speaker costs. 
In the above model, based on the professional association literature, I hypothesized that future participation and importance of the profession would depend on the sense of social identity from the profession, past participation, program content, more innovative delivery modes like online delivery, and co-production. Definitions, theoretical rationale and measures are summarized in Table 1.

Table 1. Constructs, Definitions, Theoretical Rationale and Measures

\begin{tabular}{|c|c|c|c|c|}
\hline Construct & Conceptual Definition & Theoretical Rationale & $\begin{array}{l}\text { Illustrative Measures Used } \\
\text { in Questionnaire }\end{array}$ & References \\
\hline $\begin{array}{l}\text { Past } \\
\text { Participation }\end{array}$ & $\begin{array}{l}\text { Self-reported } \\
\text { participation in the past } \\
\text { year activities of the } \\
\text { Association. }\end{array}$ & $\begin{array}{l}\text { Past-behavior is } \\
\text { indicative of future } \\
\text { behavior. }\end{array}$ & $\begin{array}{l}\text { Can you recall having learnt } \\
\text { about or attended last year's } \\
\text { programs? (Listing of last } \\
\text { year's programs and rating } \\
\text { scale). }\end{array}$ & $\begin{array}{l}\text { Sheppard, Hartwick,\& } \\
\text { Warsaw, (1988) }\end{array}$ \\
\hline $\begin{array}{l}\text { Future } \\
\text { Participation }\end{array}$ & $\begin{array}{l}\text { Intention to participate } \\
\text { for next year. }\end{array}$ & $\begin{array}{l}\text { Depends on last year's } \\
\text { participation and } \\
\text { coming years } \\
\text { programs, schedules } \\
\text { etc. }\end{array}$ & $\begin{array}{l}\text { Several questions relating to } \\
\text { content, location that might } \\
\text { promote future participation. }\end{array}$ & $\begin{array}{l}\text { Sheppard, Hartwick \& } \\
\text { Warsaw, (1988) }\end{array}$ \\
\hline $\begin{array}{l}\text { Program } \\
\text { Content }\end{array}$ & $\begin{array}{l}\text { Professional } \\
\text { associations are } \\
\text { expected to provide } \\
\text { training in both basics } \\
\text { and the latest best } \\
\text { practices and research } \\
\text { results to their } \\
\text { members. }\end{array}$ & $\begin{array}{l}\text { Organizations must } \\
\text { provide the core } \\
\text { service that their } \\
\text { customers are paying } \\
\text { for. }\end{array}$ & $\begin{array}{l}\text { For next year - (names of } 19 \\
\text { programs)- rate them into } \\
\text { how successful they might } \\
\text { be }- \text { from Very Successful } \\
\text { to Not Successful ( } 5 \text { point). }\end{array}$ & $\begin{array}{l}\text { Parasuraman, } \\
\text { Berry,\&Zeithaml,(199 } \\
\text { 1) } \\
\text { Gruen,Summers,\&Acit } \\
\text { o, (2000) }\end{array}$ \\
\hline $\begin{array}{l}\text { Delivery } \\
\text { Mode }\end{array}$ & $\begin{array}{l}\text { Mode of delivery of } \\
\text { programs including } \\
\text { various electronic } \\
\text { deliveries. }\end{array}$ & $\begin{array}{l}\text { Easier it is to } \\
\text { logistically participate } \\
\text { in a program more } \\
\text { likely will the } \\
\text { professional } \\
\text { participate. }\end{array}$ & $\begin{array}{l}\text { How likely is your company } \\
\text { to pay for webinars, online } \\
\text { based tutorials, podcasts? }\end{array}$ & $\begin{array}{l}\text { Buch \& Bartley, } \\
\text { (2002) } \\
\text { Singh, (2003) }\end{array}$ \\
\hline $\begin{array}{l}\text { Co- } \\
\text { production }\end{array}$ & $\begin{array}{l}\text { Programs offered by } \\
\text { Association members. }\end{array}$ & $\begin{array}{l}\text { Members should be } \\
\text { happy to learn from } \\
\text { other members who } \\
\text { have expertise in } \\
\text { certain areas. }\end{array}$ & $\begin{array}{l}\text { How successful will a Basic } \\
\text { Purchasing Program be that } \\
\text { is conducted by an } \\
\text { experienced member? }\end{array}$ & $\begin{array}{l}\text { Sheth,\&Parvatiyar, } \\
\text { (1993) }\end{array}$ \\
\hline $\begin{array}{l}\text { Social } \\
\text { identity }\end{array}$ & $\begin{array}{l}\text { How much the member } \\
\text { identifies herself or } \\
\text { himself with the } \\
\text { Association? }\end{array}$ & $\begin{array}{l}\text { More the identification } \\
\text { with the Association } \\
\text { more the engagement. }\end{array}$ & $\begin{array}{l}7 \text { item scale including "when } \\
\text { someone criticized our } \\
\text { association it feels like a } \\
\text { personal insult." }\end{array}$ & $\begin{array}{l}\text { Bhattacharya, Rao,\& } \\
\text { Glynn, (1995) } \\
\text { Bhattacharya, (1998) }\end{array}$ \\
\hline $\begin{array}{l}\text { Importance of } \\
\text { Profession in } \\
\text { member } \\
\text { Organization }\end{array}$ & $\begin{array}{l}\text { Is the importance the } \\
\text { profession rising in your } \\
\text { organization? }\end{array}$ & $\begin{array}{l}\text { Engaged members will } \\
\text { champion the } \\
\text { profession's cause }\end{array}$ & $\begin{array}{l}\text { Is the importance of the } \\
\text { purchasing profession } \\
\text { increasing in your } \\
\text { organization? }\end{array}$ & $\begin{array}{l}\text { Ross, (2005) } \\
\text { Welch,\&Bryne, (2001) }\end{array}$ \\
\hline $\begin{array}{l}\text { Social } \\
\text { Marketing } \\
\text { and Corporate } \\
\text { Social } \\
\text { Responsibility } \\
\text { (CSR) } \\
\text { initiatives }\end{array}$ & $\begin{array}{l}\text { Related CSR initiatives } \\
\text { taken up by member in } \\
\text { her/his organization. }\end{array}$ & $\begin{array}{l}\text { Engaged members will } \\
\text { attend the CSR } \\
\text { programs and } \\
\text { champion them in their } \\
\text { organization }\end{array}$ & $\begin{array}{l}\text { Have you taken up } \\
\text { "greening" the supply chain } \\
\text { or supplier diversity } \\
\text { programs in your } \\
\text { organization? }\end{array}$ & $\begin{array}{l}\text { Rao, (2002) } \\
\text { Worthington et. al., } \\
\text { (2008) }\end{array}$ \\
\hline
\end{tabular}

I now present a more detailed account of the logic surrounding the hypotheses 


\subsection{Past Participation}

Past behavior is a good indicator of future behavior (Ouellette, \& Wood, 1998; Sheppard, Hartwick, \& Warsaw, 1998). As Oulette and Wood (1998) argue, past behavior becomes a habit in time. A habit gives a sense of stability to the individual who may be otherwise dealing with several other uncontrollable situations in day to day life.

A defining characteristic of professional chapter meetings is that these tend to be in the local area that are easy to travel to. When the local association has a building, the location becomes fixed. Where the association does not have its own local building, the leadership is able to offer its own premises (e.g. A Professor who can help access the use of an available meeting room at the university). Finally, if both are not possible, a fixed restaurant or hotel serves as a meeting place. Overall, there is a sense of stability and travel accessibility for the participant who starts participating in chapter meetings.

Thus, I argue that those members who have attended events in the current year are more likely to attend events in the next year compared to those members who did not attend any events at all. In the context of our empirical study any member who has come to the seminar location once is likely to be more familiar with the route, traffic conditions and a general feel of the typical event. In addition, these members would expect to see some "known faces" if not friends at the event that encourages them to attend. These experiences make it more likely for such a member to attend an event in the future.

Formally:

$H_{1}$ Participation in association events in the past will make it more likely that the member will participate in the future and enhance social identity with the profession.

\subsection{Program Content}

The educational and program content of workshops/seminars and events are critical to a professional association's offerings. Members attend the association events as education and training is the primary aim of the association. Members want to learn the latest in their profession to enhance their skills and competence. By offering such programming content, associations offer appropriate service that is fundamental to the existence of any service organization (Parasuraman, Berry, \&Zeithaml, 1991) and relevant to professional associations (Gruen, Summers \&Acito, 2000).

Continuing professional development is an important aim of professional organizations. The continuing professional development of nurses and nursing knowledge is an important field of study (e.g. Pool et. al., 2016). In an in-depth interview of 21 nurses Pool et. al. (2016) find that one of the important goals of professional development is to deepen knowledge which is the main reason for nurses attending professional conferences. As noted earlier, the advantage of programs run by local professional associations is that members are able to attend programs for free.

Thus, if the program content deepens the knowledge of the member in her/his professional field, there would be a motivation to attend.

Professional associations, in turn, must offer training and education opportunities that update the skills of the members in a timely, topical and engaging manner.

Formally:

$\mathrm{H}_{2}$ : The more relevant the content of an association event the more likely the member is to attend such an event and have a positive perception of the role of the profession in the member's organization.

\subsection{Delivery Mode}

Colleges are trying to improve their delivery mode through online and hybrid classes. In addition, colleges also offer classes near the workplace of the adult student's organization. In particular, online delivery of programs has become both relevant and preferred (Buch \& Bartley, 2002; Singh 2003).

For working professionals, the commute time taken to attend a continuing professional education event becomes a deterrent to attendance and engagement with the professional association. Depending on the size of the state, a state association meeting might involve travel of more than an hour each way.

Accordingly, different professions have been advocating that online delivery of programs or some form of hybrid delivery viz. onground and online might facilitate attendance, engagement and professional identity. Such an approach would improve continuing professional education outcomes and engagement in social work (Cummings et. al., 2013), nursing (Clark, Draper,\& Rogers, 2015) and dentistry (Barnes et. al., 2013).

Given the increasing popularity of online programs and preliminary indications that driving and location of events is a constraint for association members, I hypothesized: 
$\mathrm{H}_{3}$ : Online delivery methods (Internet based tutorials, webinars) will facilitate attendance at association events and upon attendance will enhance the importance of the profession in member organizations.

\subsection{Co-Production}

Co-production involves member involvement in producing and delivering events (Sheth,\& Partvatiyar, 1995). Hager (2014) classifies coproduction in professional associations as part of member engagement that results in occupational advantage. The occupational advantage derives from the higher visibility that a member achieves by presenting a workshop/seminar in the association meeting. Peers recognize the individual member and this leads to occupational and career advantage and growth.

In communities Bovaird and Loeffler (2012) find that engagement comes first followed by the willingness to coproduce. However, this paper argues that a professional association member by definition has a baseline level of engagement. By co-producing events as a speaker or resource the individual member becomes even more engaged with the association.

Such member involvement should increase the sense of ownership of the association by members and should therefore enhance the member-association link. While co-production will enhance the bonding between the co-producing member and association the literature is unclear about what effect such co-production will have on other members. Thus, if some members are say disliked by other members then it is likely that while increasing co-producing member association relationship other relationships are adversely affected. Conversely if all members like each other then any co-production will enhance member engagement all across the membership Thus:

$\mathrm{H}_{4}$ : Co-production of programs will enhance member social identity and the status of the profession in organizations.

\subsection{Social identity}

The sense of social identity or oneness that members feel with the organization or association can have a large influence on the extent of member engagement (Bhattacharya, Rao, \& Glynn, 1995; Bhattacharya, 1998). Based on social identity theory (Tjafel, 1981), more the member identifies with the association more likely will be the attention that members will give to the association's events and the motivation members will have to attend the events. Thus, following (Hoeve et. al., 2014) a nurse who sees her professional identity as a nurse will be attentive to messages from her local chapter and be motivated to attend chapter meetings.

Social identity as a variable should influence member engagement both directly and as a moderator. Thus, if members have a strong sense of social identity, they will attend events and be more engaged with the association. In addition, with a higher sense of social identity all the other pre-cursors of engagement will be enhanced. Thus, for example if social identity is high then co-production might be more than when social identity is low.

A strong social identity of members as association members will enhance the prestige of association in the member's organization as members will advocate the perspective of their own profession in their organizational settings following social identity theory (Ethier, \&Deaux, 1994). Such a social identity will thus lead to a more positive impression of the profession in the member organization.

$H_{5 a}$ : The greater the social identity as an association member, greater the engagement with association and more the importance of the profession in the member's organization.

$H_{5 b}$ : Social identity will moderate the impact of direct variables like program content, delivery mode and coproduction. Greater the social identity greater will be the effect of social identity-direct variables on the importance of the profession in the organization.

\subsection{Context and Method of Study}

Purchasing managers or supply managers are critical individuals in organizations that can further corporate social responsibility initiatives (Laczniak, Lusch, \& Murphy, 1979) including major social marketing challenges of our time including "greening" the supply chain (Rao, 2002), and increasing diversity of suppliers (Worthington et. al., 2008). I study a state affiliate of the National Association of Purchasing Management (NAPM) now called Institute of Supply Management (ISM www.ism.ws). The author had close access to the ISM Affiliate (referred to as association in this paper) that was researched. The association has over 400 members and a Board of Director and a more Senior Board of Advisers. The Board of Advisers was concerned about the poor attendance in the previous year's programs. The association advisers requested the author to conduct a survey based on discussions at the advisers meeting as to how the association might better engage its members for the next year. 
I conducted a preliminary literature review and included the "social identity construct". The draft survey was hosted online (using an Internet survey platform) and several Board members tried the draft survey and suggested changes in wordings of the questions

The surveys are made anonymous breaking from traditional association practice where event feedback forms have place for members to fill up their name and contact details.

Once the questionnaire was approved by the Board of Advisers, the link and cover email from the President of the association was sent out to the members from the association office. After one reminder 102 responses (21\%) Ire received in a period of 12 days that the survey was kept open. No significant differences in response levels were observed between early and late responders. The survey software indicated the IP addresses of respondents and distinct 102 different IP addresses were reported.

The responses had options of adding comments that are presented in the measure's tables. with the appropriate measures.

\subsection{Analysis and results}

I recoded our dependent variable "profession" into a dummy binary variable that classified respondents to two categories. The first are those who believed (75.5\%) that supply management was becoming more important in their organizations and their organizations were looking to the association member for leadership. The second category (total 24.5\%) are those members who felt that while supply management was becoming more important in their organizations (15.3\%) either other professionals had taken the leadership (as in IT outsourcing) or the function had become more dissipated and all professionals did purchasing themselves without going through the purchasing department $(9.2 \%)$.

I ran three different combinations of logistic regression models with the direct effects of past participation, program content, delivery mode, co-production and social identity on importance of the purchasing profession in the members' organization to test the direct effect hypothesis from $\mathrm{H} 1$ to $\mathrm{H} 5$. I next ran the moderating effects model by multiplying the social identity value with each of the other variables viz. past participation, program content, delivery mode, coproduction.

Given the relatively low number of observations I used the entire dataset for modeling and did not go for holdout samples for evaluating goodness of fit and classification. Instead, I examined the Hosmer and Lemeshow test result (Hosmer, \&Lemeshow, 2001) to evaluate the goodness of fit of each model.

Between the direct effects model (Hypothesis 1 to 5a) and the moderating effects of social identity model (H5b) in the second model the Hosmer and Lemeshow test significance was below 0.05 indicating that social identity operates as a moderating variable. The moderator model also had better overall classification rate at $84.9 \%$. The results of these two models are presented in Table 2. Thus, social identity has strong moderating effects with the variables of past participation; program content; delivery mode and co-production. Examined as a direct effect, social identity alone does not appear (H5a) to be a significant predictor of importance of purchasing. However, the moderating impact of social identity with predictor variables likes content, delivery mode and co-production lends strong support (H5b) to the moderating effect of social identity on member engagement and importance of purchasing.

Table 2. Results of three logistic regression runs as per conceptual model of Figure 1

$\left.\begin{array}{|l|l|l|l|l|l|l|l|}\hline \begin{array}{l}\text { Variables } \\ \text { (Construct) }\end{array} & \begin{array}{l}\text { Chi } \\ \text { Square }\end{array} & \text { Sig } & \begin{array}{l}\text { Cox and } \\ \text { Snell R } \\ \text { square }\end{array} & \begin{array}{l}\text { Nagelkerke R } \\ \text { Square }\end{array} & \begin{array}{l}\text { Percentage } \\ \text { Correct Purchasing } \\ \text { Profession } \\ \text { Becoming } \\ \text { important }\end{array} & \begin{array}{l}\text { Percentage } \\ \text { Correct } \\ \text { Purchasing } \\ \text { Profession } \\ \text { Becoming } \\ \text { important }\end{array} \\ \text { less } \\ \text { Prediction \% } \\ \begin{array}{l}\text { Direct effects of past } \\ \text { participation, program content, } \\ \text { delivery mode, co-production } \\ \text { and social identity (H1 to H5a) }\end{array}\end{array}\right)$




\subsection{Implications for Social Psychology}

Professionals engage with their core profession through ongoing professional development via education and networking in professional associations. As examined in the empirical part of this paper, purchasing and supply management professionals are responsible for at least two corporate social responsibility (Laczniak, Lusch, \& Murphy,1979) initiatives viz. more environmentally friendly or "green" supplies (Rao, 2002), and diversity in suppliers (Worthington et. al., 2008). The sense of engagement professionals feel with their professional associations should predict the social marketing that may be done by such professionals in their organizations (following Laczniak, Lusch, \& Murphy, 1979).

The sense of social identity or oneness that members feel with the organization or association can have a large influence on the extent of member engagement. Social identity of the professional with her profession and consequent involvement in social marketing has been identified as an important determinant of member engagement (Bhattacharya, Rao, \& Glynn, 1995; Bhattacharya, 1998). Such engagement This paper examined the link of program content, social identity -engagement with the professional association and the perceived importance of the profession in the member's organization. The paper offers a model and conducts a survey of association members and finds that social identity alone is not a significant predictor of the perceived importance of profession and its social marketing efforts. Social identity operates interactively with other relevant variables like past participation, program content, delivery mode of association programs.

\subsection{Limitations and further research}

This research was conducted for the supply/purchasing management in one local state chapter in the USA. The particular profession is found embedded in organizations that have other professions (e.g. Finance, Marketing) who are also competing for influence within the organization. This study while high in validity, is worth replicating in other organizationally embedded professions like nursing in hospital settings.

Future research is needed around specific learning and social interaction themes and the link of the engagement of professionals with their professional associations. There may be several professional associations that speak to a particular social cause and studying the multiple association-member engagement links should provide more insight into the association-member-social marketing link. For example, AIDS awareness is part of programming of several professional associations like physicians, nurses, social workers, school teachers, community health workers. Interesting research should result from studying the AIDS programming content of these associations, their members' engagement and the impact of AIDS awareness in the target community.

\section{References}

AAPC. (2018). 2018 AAPC local chapter handbook. Accessed February 24, 2019. Retrieved from https://www.aapc.com/documents/20181c_handbook_print.pdf

Bovaird, T., \& Elke, L. (2012). From engagement to co-production: The contribution of users and communities to outcomes and public value. Voluntas: International Journal of Voluntary and Nonprofit Organizations, 23(4), 1119-1138.

Bhattacharya, C B., Rao, H., \& Glynn, M.A. (1995). Understanding the bond of identification: An investigation of its correlates among art museum members. Journalof Marketing, 59(4), 46-57.

Bhattacharya, C. B. (1998). When customers are members: Customer retention in paidmembership contexts. Journal of Academy of Marketing Science., 26(1), 31-44.

Buch, K. \& Bartley, S. (2002). Learning style and training delivery mode preference. Journal of Workplace Learning, 14(1), 5-10.

Cannon, J.P., \& Homburg, C. (2001). Buyers-supplier relationships and customer firmcosts. Journal of Marketing, 65 (1), 29-43.

Clark, E., Draper, J., \& Rogers, J. (2015). Illuminating the process: enhancing the impact of continuing professional education on practice. Nurse Education Today,35(2), 388-394.

Cummings, S. M., Foels, L., \& Chaffin, K. M. (2013). Comparative analysis of distance education and classroom-based formats for a clinical social work practice course. Social Work Education,32(1), 68-80.

Ethier, K. A., \&Deaux, K. (1994). Negotiating social identity when contexts change: Maintaining identification and responding to threat. Journal of personality and social psychology, 67(2), 243.

Greenwood, R., Suddaby, R. \&Hinings, C.R. (2000). Theorizing Change: The Role ofProfessional Associations in the transformation of institutionalized fields. Academy of Management Journal, 45 (1), 58-80. 
Gruen, T. W., Summers, J.O. \&Acito, F. (2000). Relationship marketing activities, commitment, and membership behaviors in professional associations. Journal of Marketing, 64 (3), 34-49.

Hager, Mark A. (2014). Engagement motivations in professional associations. Nonprofit and Voluntary Sector Quarterly, 43(2), 39S-60S.

Hoeve, Y., Jansen,G., \&Roodbol, P. V. (2014). The nursing profession: public image, self-concept and professional identity. A discussion paper. Journal of Advanced Nursing, 70(2), 295-309.

Hosmer, D.W., \&Lemeshow, S. (2001). Applied Logistic Regression: Wiley, New York.

Laczniak, G. R., Lusch, R. F. \& Murphy, P.E. (1979). Social Marketing: its Ethical Dimensions. Journal of Marketing, 43 (2), 29-36.

Mair, J., \& Thompson, K. (2009). The UK association conference attendance decision-making process. Tourism Management, 30(3), 400-409.

Parasuraman, A., Berry, L. L. \&. Zeithaml, V.A. (1991). Understanding Customer Expectations of Service. Sloan Management Review, 32 (3), 39-48

Pool, I. A., Poell, R. F., Berings, M. G., \& Ten Cate, O. (2016). Motives and activities for continuing professional development: An exploration of their relationships by integrating literature and interview data. Nurse education today, 38, 22-28.

Postmes, Tom, Alexander Haslam, S. \&Swaab, R. I. (2005). Social influence in small groups: An interactive model of social identity formation. European review of social psychology 16(1), 1-42.

Ouellette, J. A., \& Wood, W. (1998). Habit and intention in everyday life: The multiple processes by which past behavior predicts future behavior. Psychological bulletin, 124(1), 54.

Rao, Purba. (2002). Greening the supply chain: A new initiative in South East Asia. International Journal of Operations \& Production Management, 22 (5/6), 632-55.

Rusaw, A. C. (1995). Learning by association: Professional associations as learning agents. Human Resource Development Quarterly, 6(2), 215-226.

Sheppard, B. H., Hartwick, J., \&Warshaw, P. R. (1988). The Theory of Reasoned Action: a meta-analysis of past research with recommendations for modifications and future research. Journal of Consumer Research,15 (3), 325-43.

Sheth, J. N. \&Parvatiyar, A. (1993). Relationship Marketing in Consumer Markets: Antecedents and Consequences . Journal of Academy of Marketing Science, 23 (4), 255-71.

Singh, H. (2003). Building Effective Blended Learning Programs. Educational Technology, 43 (6), 51-54.

Tajfel, H. (1981). Human groups and social categories. Cambridge, England: Cambridge University Press.

Welch, J. F. \&Bryne, J.A. (2001). Straight from the gut. New York: Warner Business Books.

Weddle, D. O., Himburg, S. P., Collins, N. \& Lewis, R. (2002). The professional development portfolio process: Setting goals for credentialing. Journal of the American Dietetic Association, 102(10), 1439-1444.

Wilson, E. J., \& Woodside, A. G. (2001). Executive and consumer decision processes: Increasing useful sensemaking by identifying similarities and departures. The Journal of Business \& Industrial Marketing, 16 (5), 401.

Worthington, I., Ram, M., Boyal, H., \& Shah, M. (2008). Researching the Drivers of Socially Responsible Purchasing: A Cross-National Study of Supplier Diversity Initiatives. Journal of Business Ethics, 79(3), 319-31. 